\title{
Role of Thyroid Gland in Prenatal Development-A Mini Review
}

\author{
R Menaka and Gopal Puri* \\ College of Veterinary Science \& Animal Husbandry, India
}

Submission: September 22, 2017; Published: October 17, 2017

*Corresponding author: Gopal Puri, College of Veterinary Science \& Animal Husbandry, Navsari Agricultural University, Navsari-396 450 (Gujarat), India, Email: drgopalpuri@gmail.com

\begin{abstract}
The thyroid gland is the first glandular structure to form and develops as a ventral midline as endodermal diverticulum from the floor of the foregut. The thyroid gland regulates the physical and chemical processes that occur at the cellular level. Thyroid hormones directly involved in the mammalian metabolism by a thermogenic in turns increase the amount of heat produced at a given time accelerating body growth and development and increasing cardiac function. The interrelationship of thyroid glands with body-growth and marked variations takes place viz in location, gross, histological and follicular activity during prenatal life.
\end{abstract}

Keywords: Thyroid gland; Foregut; Thermogenic; Hormones; Cardiac.

\section{Introduction}

Thyroid gland word derived from Greek "Thyreos" means an oblong shield and "Edios" means form. The gland appears to have longest phylogenetic history than any other endocrine glands in the body [1]. The thyroid gland is the largest classic endocrine organ, which effects many organs of the body and plays a significant role in the process of metabolism in animals [2]. The most numerous cell populations in the gland is the thyroid follicular cells which are responsible for secretion of iodated tyrosine derived hormones which exert important effects on development growth metabolism of the organ system [3].

Todini [4] stated that it regulates reproduction, productive performance such as growth, milk and hair fiber production in domestic animals and hence its level affects the farm animal productivity. Thyroid hormones also affects mammalian metabolism by a thermogenic action in which carbohydrate, lipid and protein metabolism can be accelerated in tissues and in turns increase the amount of heat produced at a given time accelerating body growth and development and increasing cardiac function [5]. Thyroid hormones (TH) are multipurpose systemic regulators of fetal and juvenile development and play a major role in adult metabolic homeostasis. Most tissues and organs respond to $\mathrm{TH}$ and consequently its cumulative effects may be measured by systemic oxygen consumption and metabolic rate. The diversity of cell types modulated by $\mathrm{TH}$ activity implicates its importance. Some of the major systems affected by TH include the heart, muscle, liver, bone, brain, and skin [6].

\section{Role of the thyroid gland in the prenatal stage}

The role of the thyroid gland in vertebrates is crucial to the general metabolism of the organism and the expression of this role is dependent on the age, nutrition and environment, especially climatic factors. It is therefore reasonable to expect certain structural and functional variations which modulate the function of the thyroid during development. In human and animal studies showed that thyroid hormones play a crucial role in nervous, cardiovascular, immune and reproductive system development and function [7]. The magnitude of the growth of different parts and body segments of fetuses varies at specific stage of development. The interrelationships of thyroid glands as a model in relation to the body-growth of fetuses were observed in goat prenatal development [8]. Marked variation in location, gross and histological features of thyroid gland in different vertebrates have been observed [9].

\section{Biometrical Differences}

The absolute weight of the gland only showed highly significant as deviation with body weight from 3rd month of gestational age onwards in fetuses of goats. The thyroid weight varies amongst domestic and wild animals depending on the diet, size and weight of the animal [10]. 
Igbokwe et al. [11] reported in white Fulani (Zebu) cattle fetal age group of 90-140 days that the weight of the thyroid gland was $0.37 \pm 0.01 \mathrm{mg}$, length of the thyroid gland was $0.51 \pm 0.01 \mathrm{~cm}$, the width of the thyroid gland was $0.42 \pm 0.01 \mathrm{~cm}$ and thickness of the thyroid gland was $0.41 \pm 0.01 \mathrm{~cm}$. In white Fulani (Zebu) cattle fetal age group of 150-210 days the weight of the thyroid gland was $0.80 \pm 0.01 \mathrm{mg}$, length of the thyroid gland was $1.26 \pm 0.01 \mathrm{~cm}$, the width of the thyroid gland was $0.50 \pm 0.01 \mathrm{~cm}$ and thickness of the thyroid gland was $0.47 \pm 0.01 \mathrm{~cm}$. In white Fulani (Zebu) cattle fetal age group of 225-260 days the weight of the thyroid gland was $2.35 \pm 0.62 \mathrm{mg}$, length of the thyroid gland was $2.23 \pm 0.04 \mathrm{~cm}$, the width of the thyroid gland was $1.50 \pm 0.01 \mathrm{~cm}$ and thickness of the thyroid gland was $0.74 \pm 0.02 \mathrm{~cm}$. Gross morphometry of thyroid gland showed that all measured parameters increased with increasing developmental age and significantly varied $(p<0.05)$ from each age group, except width of the thyroid lobe during the fetal age 90-140 days. The isthmus was consistently present between the 1st to the 3rd tracheal ring in all fetuses in white Fulani (Zebu) cattle.

The thyroid weight increased with age for instance, the lobes were weighed about $0.05 \pm 0.001 \mathrm{~g}$ in 50 days to 70 days of fetuses, 75 to 90 days of development mean weight about $0.22 \pm 0.001 \mathrm{gm}$ and 95 to 125 days of thyroid weight about $0.38 \pm 0.04 \mathrm{~g}$ observed in West African Dwarf (WAD) goat [12].

Anupriya \& Kalpana [13] observed that the mean and range of length of thyroid lobe of human fetus during 10-17 weeks was $5.6 \mathrm{~mm}(3-9)$, the mean and range of length of thyroid lobe of human fetus during 18-22 weeks was $9.5 \mathrm{~mm}$ (9-12) and the mean and range of length of thyroid lobe of human fetus during 23-36 weeks was $12.1 \mathrm{~mm}(7-18)$. The mean and range of breadth of thyroid lobe of human fetus during 10-17 weeks was $2.8 \mathrm{~mm}(2-4)$, the mean and range of breadth of thyroid lobe of human fetus during $18-22$ weeks was $4.2 \mathrm{~mm} \mathrm{(3-6)}$ and the mean and range of breadth of thyroid lobe of human fetus during 23-36 weeks was $4.5 \mathrm{~mm}$ (2-6). The mean and range of thickness of thyroid lobe of human fetus during 10-17 weeks was $1.8 \mathrm{~mm}$ (1-4), the mean and range of thickness of thyroid lobe of human fetus during 18-22 weeks was $2.75 \mathrm{~mm}(2-4)$ and the mean and range of thickness of thyroid lobe of human fetus during 23-36 weeks was $2.9 \mathrm{~mm}(2-5)$.

\section{Conclusion}

The development and function of the thyroid gland play a crucial role in the prenatal life. The fetal thyroids actively involved in the secretion of colloidal compound and stored as well in the thyroid follicles for fetal growth. The fetus entirely depends on maternal thyroidal hormones for the first 90 days of gestation, until the fetuses' thyroid begins to produce on its own. In human fetuses of first trimester are completely dependent on the mother for thyroid hormones necessary for brain development.

\section{References}

1. Ingbar SH (1985) The thyroid gland. In: Textbook of Endocrinology. Saunders, Philadelphia, USA, pp: 682-815.

2. Yadegari M, Azizi S, Khamesipour F (2014) Evaluation of prevalence of the types of thyroid disorders using ultrasound and pathology of one humped camel (Camelus dromedarius). Kafkas Universitesi Veteriner Fakultesi Dergisi 20(4): 605-611.

3. Cabello G, Wrutnaik C (1989) Thyroid hormone and growth: relationship with growth hormone effects and regulation. Reprod Nutr Dev 29(4): 387-402.

4. Todini $\mathrm{T}$ (2007) Thyroid hormones in small ruminants: Effects of endogenous, environmental and nutritional factors. Animal 1(7): 9971008.

5. Norris DO (2007) Vertebrate Endocrinology. Philadelphia, $4^{\text {th }}$ (edn.), Elsevier. Academic press. London. pp: 221-223.

6. Yen PM (2001) Physiological and molecular basis of thyroid hormone action. Physiol Rev 81(3): 1097-1142.

7. Janini EA, Ulisse S, Armento DM (1995) Thyroid hormone and male gonadal function. Endocr Rev 16(4): 443-459.

8. Malik MR, Parmar ML, Pillai PVA (1997) Prenatal growth changes of thyroid gland in goats. Indian Journal of Animal Sciences 67(9): 774776.

9. Dyce KM, Sack WO, Wensing CJG (2002) Textbook of Veterinary Anatomy. Elsevier, London. pp: 213-215.

10. Little GJ (1991) Thyroid morphology and function and its role in thermoregulation in newborn southern elephant. J Anat 176: 55-69.

11. Igbokwe CO, Machebe NS, Ezeasor DN (2014) Age-related morphological changes in the foetal thyroid gland of white Fulani (zebu) cattle. Indian Journal of Animal Research 48(5): 438-443.

12. Igbokwe CO, Ezeasor DN (2015) Gross and morphometric anatomical changes of the thyroid gland in the West African Dwarf goat (Capra hircus) during the fetal and postnatal periods of development. Nigerian Veterinary Journal 36(4): 1272-1282.

13. Anupriya A, Kalpana R (2016) Morphological and histological features of human fetal thyroid. International Journal of Scientific Study 3(10): 136-140. 
This work is licensed under Creative
Commons Attribution 4.0 Licens
DOI: 10.19080/JDVS.2017.04.555634 